\title{
Durable Electricity Power W. S. H. (Wind, Solar, and Hydro)
}

\author{
Ahmed Mohamed Ahmed Hassan \\ Kafr Elsheikh STEM High School \& Cairo University Faculty of Engineering, Nasr City, Cairo, Egypt \\ ahmedHassan200282[at]gmail.com \\ ORCid: https: //orcid. org/0000-0002-7130-8980
}

\begin{abstract}
The tendency towards alternative types of energies is becoming popular since the 2000s because their advantages are more than their drawbacks. They produce fewer greenhouse gases, with renewable sources, and decrease unemployment rates. Although their problem is with their total cost, it is in the way of being solved by the simultaneous advancements. This research paper focus on three alternative sources of energy that could be at least one of them be used globally, specifically in Egypt, which are wind power, solar power, and hydropower. The main aim of this paper is to use cotemporary techniques used in some places worldwide and manipulate their characteristics to be applied in and optimized for Egypt. The project is on a large scale because the research started on various types of alternative energies, like tidal power, Biomass, wind, geothermal, biofuels, solar, hydropower, wave energy, and nuclear power, and concluded to these three main types, because of three main restrictions, which are the accessibility, the number of searches done on that field, and the abundance of this resource. Thus, Wind power, Solar power, and Hydropower were chosen to be the main durable electricity power "W. S. H. " The team found, by applying calculations and constructing specific devices for each type of these W. S. $H$ source, that Egypt could have sufficient electricity from just those three fields. for example, Egypt could produce about one and a half the electricity generated by the USA from just half the total areas without the national restricted areas. Through solar power, Egypt could produce as much as the electricity in the USA (Egypt is about 1/10 of America's area). Besides, the Qattara Depression has the potential to produce enough electricity for industry.
\end{abstract}

Keywords: offshore farms and systems, photovoltaic cells, Qattara Depression, and wind power, solar power, hydropower (WSH).

\section{Introduction}

The Egyptian New and Renewable Energy Authority (NREA) estimates that energy consumption will be doubled by 2022 due to population increase and development [5]. The main and most plentiful types of renewable energy in Egypt are hydropower, wind energy, Biomass, and solar energy resources (fig 1). This research paper is focused on hydropower, wind energy, and solar energy because they are the accessible kinds in Egypt that do not require much money or effort to develop or to generate according to (NREA).

Firstly, this paper used subjects-based research target, which is to use essential science facts and laws to bolster the process of researching for information. [7] was used to understand and to interact with the various chemical hydrocarbon compounds (alkanes and isomers). For example, the insulation material ethylenedioxythiophene $\mathrm{C} 2 \mathrm{H} 4 \mathrm{O} 2 \mathrm{C} 4 \mathrm{H} 2 \mathrm{~S}$ is used on the Photovoltaic cells. [7] is in this part to calculate the amount of greenhouse gases produced through the alternative energies and compare them to the amount of produced greenhouse gases produced from the combustion of fossil fuels. [8] was used to deduce the induced voltage, intensity, their effective value (rms) by faraday's law, and to dealt with the AC and DC generators and motors. [9] helped in calculating the power and mechanical energy for the input and output for each kind of energy. [8] sections were used to understand transformers, diodes, back and forward electro motive force (EMF), step down and up connections, AC circuits, high and low filters, and series connection of resistor, induction, capacitor (RLC).

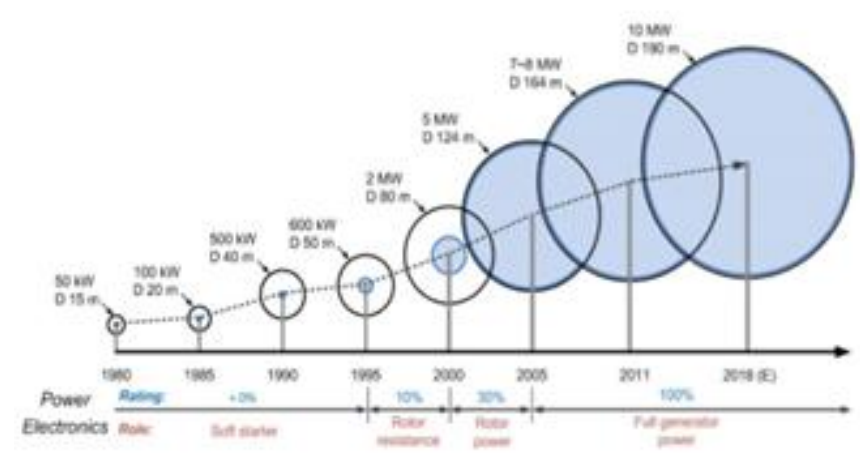

Figure 1: The relation between diameter size and electricity

This research was constructed on three main points used in the three alternative sources the paper covers: researching for developments, for applications used in Egypt that are similar or related to the developments searched and researching for peers (countries) that applied them. First the wind energy, after researching about the recent development and installment of wind energy all over the world (capacity), it is obvious that most of the world is going to generate $50 \%$ of electricity from wind energy only, and this is also true for Egypt. This paper covers two kinds of development: turbine size, and the offshore wind energy potential in Egypt. Also, it provides a recent comparison between (USA and Denmark) that applied those methods and the hypothetical results in Egypt from applying them. Secondly, modifications that can be applied to solar cells that generate electricity from the sun were researched. These modifications are in the way of colling the solar cells so reducing the amount of thermal energy wasted. For example, Egypt used to cool the cells by using water or air or using water and air together [11]. For hydropower, 20\% of the world's electricity is supplied by hydroelectricity.

Volume 11 Issue 1, January 2022

www.ijsr.net

Licensed Under Creative Commons Attribution CC BY 


\section{International Journal of Science and Research (IJSR) \\ ISSN: 2319-7064 \\ SJIF (2020): 7.803}

Turkey is planning to develop its hydro potential to produce 85, $000 \mathrm{GWh}$. this project includes 22 dams and 19 hydroelectric plants. Hydraulic power currently accounts for $22 \%$ of the electricity generated in Egypt. Egypt generates hydroelectric power of about 2000 (MW) from the Qattara Depression.

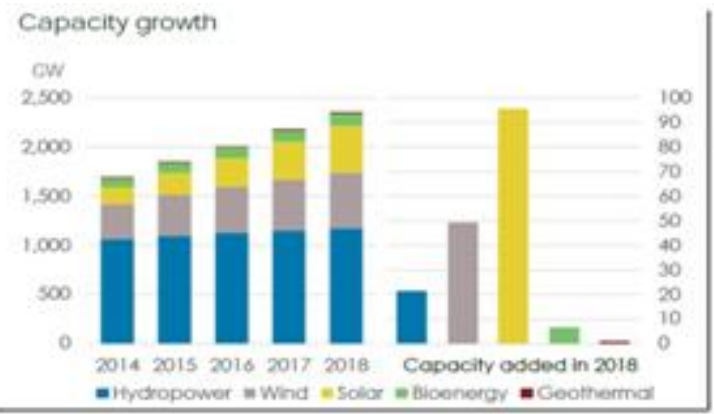

Figure 2: The capacity of different types of energies

\section{Literature Review and Analysis}

As a result of the rapid development and technological advances in human life, electricity demand has increased over the years: to meet its requirements and daily activities, to mitigate the global energy crisis, and reduce its environmental impacts. The analysis is composed of different sections for the three kinds of alternative energies that the paper covers (Wind energy, solar power, hydropower). Each comprises three portions: recent developments, the hypothetical implementation of these developments or similar applications related to them in Egypt, and the applied experience of peers (other countries) on these developments.

I-wind power: as the fast-growing capacity of wind power grid by Wind Turbine System (WTS), the power electronics technologies and planning for installment places have changed dramatically in the last 3 decades. Firstly, development is in technologies. According to [4], depending on the types of generators, power electronics, speed control ability, and the way in which the aerodynamic is limited the wind turbine designs can be categorized into different concepts; in these concepts, the power electronics play different roles in the WTS and has various power rating systems, as the increase in the size of the diameter of the wind turbine (it is noticed that by increasing the diameter the wind capacity increases) (fig 2).

The configuration of the Doubly Fed Induction Generator (DFIG) equipped with two different power scales: partialscale convertor (classic) and full-scale convertor (new). The partial-scale power convertor (fig 3), from [8], is adopted in conjunction with the DFIG. The stator windings of DFIG are directly connected to the power grid, whereas the rotor windings are connected to the power grid by the converter with normally $30 \%$ capacity of the turbine.

In this concept, the frequency and the current in the rotor can be flexibly regulated and thus the variable speed range can be extended to a satisfactory level. Main obstacles are, however, the use of slip rings and the challenging power controllability in the case of grid faults. The Two-level
Pulse Width Modulation Voltage Source Converter (2LPWM-VSC) are normally configurated in Back-To-Back convertor (BTB) in WTS (fig 4) in the form of parallel connection (fig 3 ) for convenience and reducing cost.

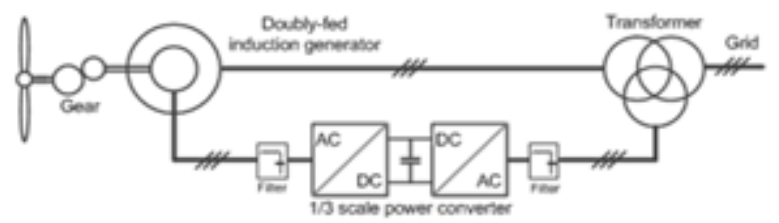

Figure 3: (BTB) parallel connection

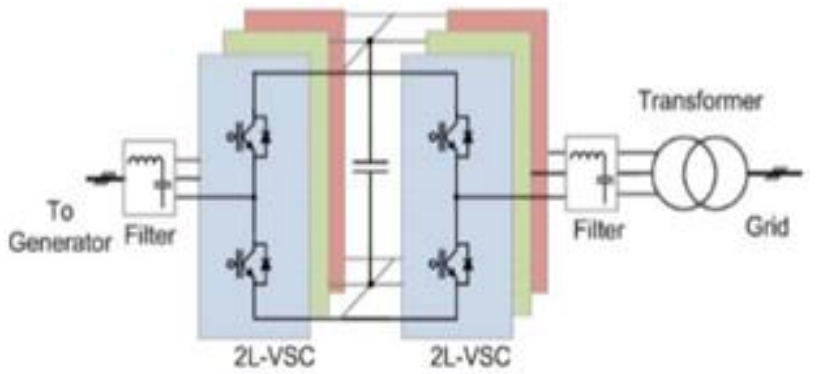

Figure 4: (BTB) normal connection

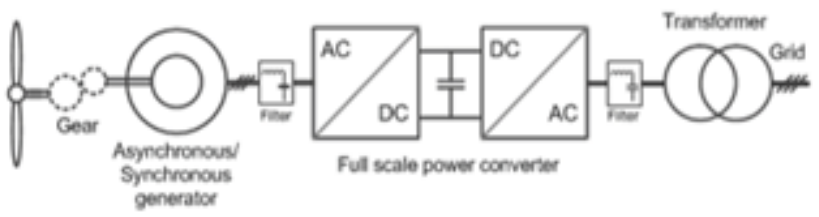

Figure 5: Modification for applying normal and parallel connection

Second concept is the full-power scale convertor. With asynchronous generator, wound rotor SG instead of DFIGbased concept, the full scale has many advantages, according to [4]: the elimination of slip rings, simpler or even eliminated gearbox, full power and speed controllability as well as better grid support ability. Also, it could be modified to have both series (fig 5) and parallel connection which is a cost effective.

Secondly, the planning development section. According to [5], the world is moving towards the offshore wind energy rather than onshore one because of the huge wind capacity availability and less restrictions. [5] used Analytical Hierarchy Process (AHP) (fig 6), an organized process to generate weighted factors to divide the decision-making procedure into a few simple steps, for sitting a wind offshore farm as the following:

- Identify the problem (wind farm spatial characteristics and related criteria)

- Standardize different factors

- Weight the importance of the various factors using pairwise comparison

Volume 11 Issue 1, January 2022 www.ijsr.net 


\section{International Journal of Science and Research (IJSR)}

ISSN: 2319-7064

SJIF (2020): 7.803

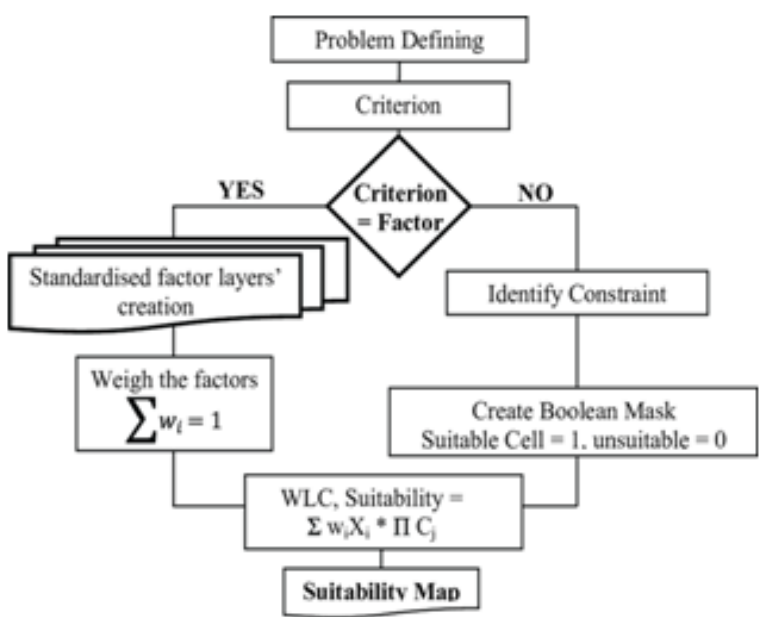

Figure 6: Analytical Hierarchy Process

Aggregate the different layers of factors and constraints using different Geographical Information System (GIS) tools and the Weighted Linear Combination (WLC).

Consistency Ratio (CR) used by [5], to validate the pairwise comparison. $\mathrm{CR}=\mathrm{CI} / \mathrm{RI}$ ( $\mathrm{RI}$ is Random Consistency Index, and CI is Consistency Index). To calculate the WLC and the suitability we must consider the factors in the following equation:

$$
\text { Suitability }=\left(\sum_{i=1}^{n}\left(W_{\mathrm{i}} X_{\mathrm{i}}\right) *\left(\prod_{j=1}^{l} C_{\mathrm{i}}\right)\right.
$$

In contrast to the onshore wind power, offshore one cost $150 \%$ more, but produce about the double amount of electricity. Applying offshore wind energy in Egypt, according to [5], it is possible to produce $33 \mathrm{GW}$ in year compared to onshore farms that produce about $1 / 2$ of this amount. After applying the AHP [5], the cost is calculated and summarized in table 1 . Besides, after subtracting the restricted areas (fig 7) from the total offshore places, there are 3 main places around the Red Sea (table 2) (fig 8).

USA (as a pear) has applied these developments mentioned before, according [6]. America has 41 sites of offshore farms about $8622 \mathrm{~km}^{\wedge} 2$, with total capacity of $23751 \mathrm{MW}$, costs about 135 million\$. And after applying offshore farms the results were: first-year price of $\$ 74 /$ megawatt-hour (MWh) (2022\$) for Phase 1 (400 MW) and \$65/MWh (2023\$) for Phase 2 (400 MW). Produce about $26.2 \mathrm{GW}$ by 2022. costs about 135 million\$. And after applying offshore farms the results were: first-year price of $\$ 74 / \mathrm{megawatt}-$ hour (MWh) (2022\$) for Phase 1 (400 MW) and \$65/MWh (2023\$) for Phase 2 (400 MW). Produce in the year of about $13.1 \mathrm{GW}$.

Table 1: Average cost and \% to total cost estimated from USD OWF costs

\begin{tabular}{|c|c|c|c|}
\hline \multicolumn{2}{|c|}{} & Cost \$m/MW & $\%$ \\
\hline \multirow{2}{*}{ Foundation } & Depth & 0.63 & 27 \\
\cline { 2 - 4 } & Soil Properties & 0.29 & 12 \\
\hline \multicolumn{2}{|c|}{ Connecting to the National Grid } & 0.20 & 5 \\
\hline Distance from shoreline (Under water cables) & 0.36 & 9 \\
\hline \multicolumn{2}{|c|}{ Installation and substations } & 0.84 & 21 \\
\hline \multicolumn{2}{|c|}{ Total } & 2.32 & 100 \\
\hline Total including the turbine & 3.67 & - \\
\hline
\end{tabular}

Table 2: Estimate wind power capacity per considered area (Figure 8)

\begin{tabular}{|c|c|c|}
\hline Location in Figure.10 & Area $\left(\mathrm{KM}^{2}\right)$ & Estimated power $(\mathrm{GW})$ \\
\hline circle 1 & 1092 & 8.6 \\
\hline circle 2 & 2137 & 16.8 \\
\hline circle 3 & 969 & 7.6 \\
\hline Total $(\mathrm{GW})$ & \multicolumn{2}{|c|}{33.0} \\
\hline
\end{tabular}

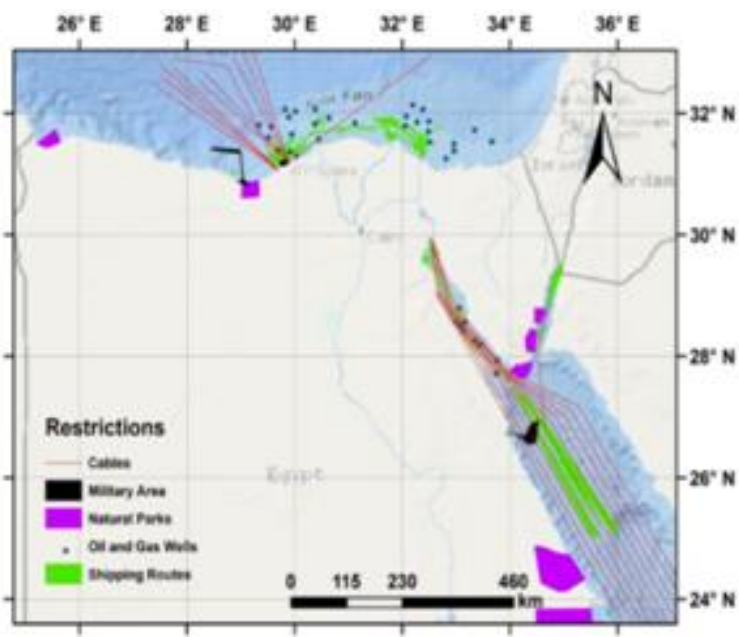

Figure 7: Restricted offshore areas in Egypt

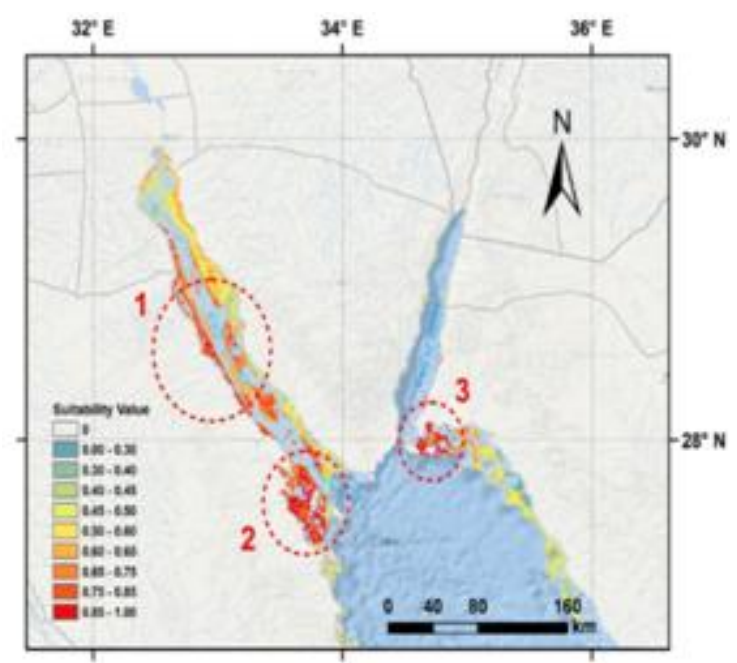

Figure 8: Allowed offshore areas for constructions

II-Solar energy: because of the common use of solar energy these days to generate electricity in a wide range of countries. Recent technological developments have made solar energy a viable alternative to generating electricity better. According to $[10,11]$, solar cells produce electricity by generating light from the sun to electricity. As the light from the sun accompanied by thermal energy that negatively affects the production of electricity. So, the development is cooling the PV models can produce the biggest amount of electricity [11]. There are three cases to cool the model:

1) Cooling with the air, in this case, the effect of air forced cooling technology in the presence of reflectors on the performance of a PV panel was investigated. to achieve this, the blower was switched on to push a cooling air into the module with reflector.

2) Cooling with water, in this case, a water pump is connected to the PV model. To achieve this, the pump

\section{Volume 11 Issue 1, January 2022 www.ijsr.net}




\section{International Journal of Science and Research (IJSR) \\ ISSN: 2319-7064 \\ SJIF (2020): 7.803}

was switched on to push cooling water into the PV module with reflector.

3) Cooling by air and water, in this case, the effect of forced air and water-cooling technologies together in the presence of reflectors on the performance of the PV module was investigated. To achieve this, the air blower and the water pump were switched on. The blower utilized to push the cooling air into the PV module with a reflector. Also, the water pump was used to push the cooling water into the PV module with a reflector at the same time (fig 9)

The previous three cases are well-known types of cooling techniques in the world. The best case is the third one in which the cooling is done with the air and the water (fig 10). In Tanta city in Egypt, these cases were tasted, and they defined that the case three will be applicated in Egypt since 2020 and the equation that used to calculate the efficiency power $($ Pmax. $=\mathrm{Wh})$ divided to hourly solar radiation $(\mathrm{G}=$ $\left.\mathrm{Wh} / \mathrm{m}^{\wedge} 2\right)$ multiplied by the surface area of $\mathrm{PV}$ panel $(\mathrm{A}=$ $\mathrm{m}^{\wedge} 2$ ) from [11].

$$
\text { nele }=\frac{P \max }{G \times A}
$$

USA is working on cooling models of PV be in a different way two main ways are cooling with air or cooling with water but not the same way in Egypt specifically cooling with water. In USA, they are using a cooling system by water by connecting an irrigation channel and some other materials (fig 11). Cooling water trickling configuration, which consists of a water trickling tube fixed on the upper edge of the PV module, water conduit at the lower edge of the module, and a bypass to deliver cooling water from the submersible pump. The trickling tube has 32 holes of $5 \mathrm{~mm}$ diameter distributed evenly from [12].

The positive effect after cooling the PV model (fig 12). The temperature reduced and by reducing it the production of electricity will be increased. The concentration of the sunrise and most places production of the electricity from the solar cells (fig 13).

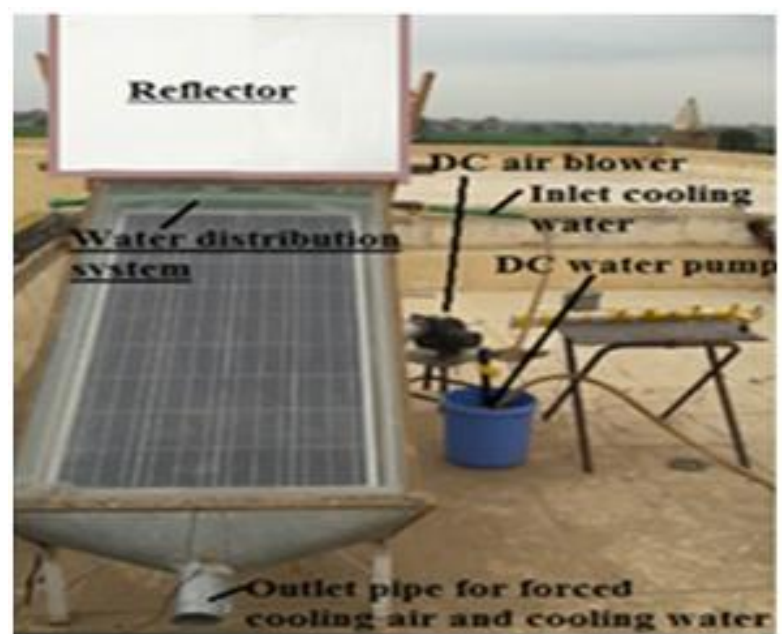

Figure 9: Reflector usage in cooling with water and air

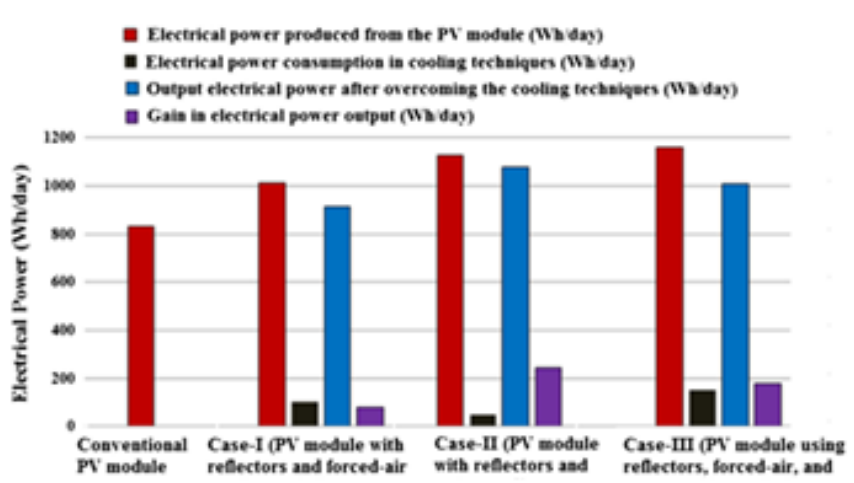

Figure 10: Comparing the three cases by using power per day

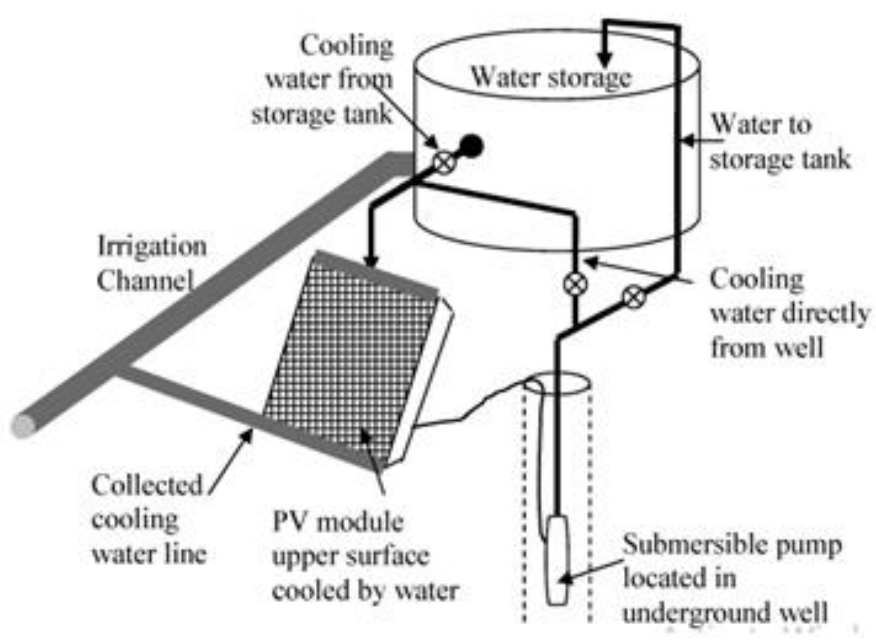

Figure 11: USA water cooling technique

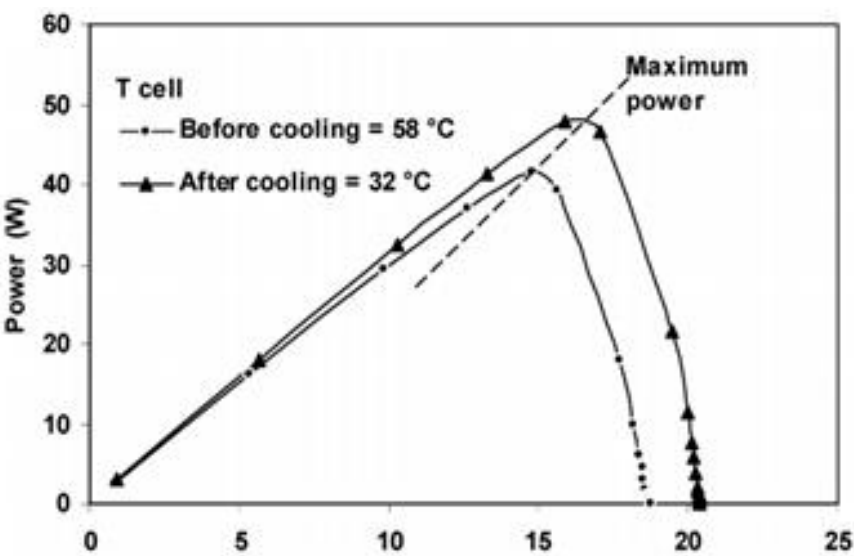

Figure 12: PV power consumption after cooling

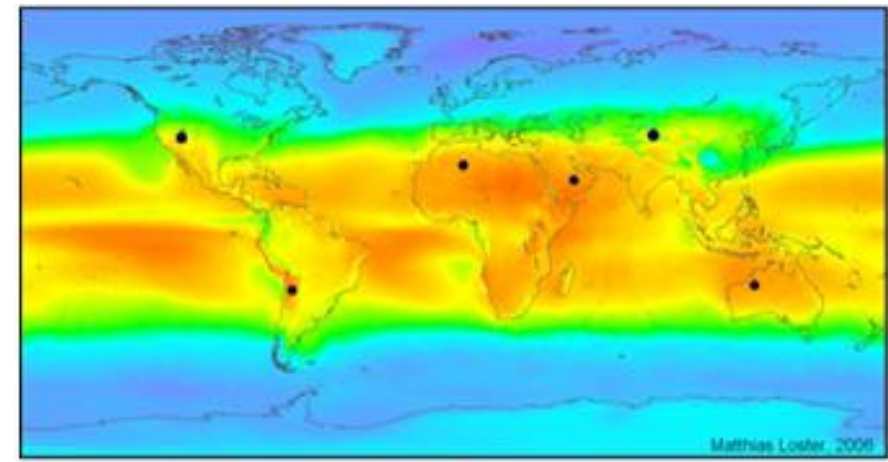

$\Sigma \bullet=18 \mathrm{TWe}$

Figure 13: Sunrise concentration map

Volume 11 Issue 1, January 2022 www.ijsr.net 
III-Hydropower Energy: when talking about renewable energy sources today, the most important and economical energy source is water for all countries around the world. Many centuries ago, mankind was already utilizing the visible power of water for mechanical drive purposes, as was the case with wind. According to [1] The hydroelectricity is the renewable energy source that distinguished by inexhaustible, nonpolluting, and more economically attractive than other options. Hydropower plants emit much less greenhouse gas than do thermal plants] 7 [(CH.2.11), greenhouse gas emissions of hydropower are caused by the decay of vegetation in flooded areas and by the extensive use of cement in the dam construction. According to 3 [, the total installed hydroelectric capacity in the world was about $660(\mathrm{GW})$ in 1997, of which about $23 \mathrm{GW}$ were small scale (plant capacity of $<10 \mathrm{MW}$ ). About $20 \%$ of the world electricity is supplied by hydroelectricity, and the total amount of hydroelectricity is $2600 \mathrm{TWH}$, of which about $3.5 \%$ is in small hydroelectric plants.

The energy demand of Turkey doubled between the years 2000 and 2010 and will be fourfold between 2000 and 2025. It has a gross annual hydro potential of $433,000 \mathrm{GWh}$, which is almost $1 \%$ of world total potential. Almost half of the gross potential is technically exploitable, and $28 \%$ (122, $322 \mathrm{GWh}$ /year) is economically exploitable. These have a total installed capacity of $11,588 \mathrm{MW}$ and an annual average generation capacity of $42,015 \mathrm{GWh}$. In the future, 329 more hydropower plants will be constructed to exploit the remaining potential of $69,326 \mathrm{GWh}$ /year, bringing the total number of hydropower plants to 483 with a total installed capacity of 34, $592 \mathrm{MW}$. it requires an investment of more than 30 billion dollars. So, after the completion of this project, which includes 22 dams and 19 hydroelectric plants, a total generation of $27,345 \mathrm{GWh} /$ year and the irrigation of an area of 1, 785, 050 ha will be realized.

In Egypt, Hydraulic power currently accounts for $22 \%$ of the electricity generated. This power is generated in 4 stations on the Nile. the first hydropower plant at the High Aswan Dam (HAD) was commissioned with a total capacity of $270 \mathrm{MW}$, it also became operational in 1968 with a total installed capacity of $2100 \mathrm{MW}$. According to [2], this study is to sustainable development for the area extends from Old Delta in Egypt to Qattara Depression. To achieve this objective, the two elements for sustainable development of this vast area, water, and power, were estimated. Water was estimated according to operation rule of (HAD) and irrigation water requirement for agriculture purposes. Power was estimated according to hydropower generation from Qattara Depression and (HAD) (fig 14).

The installed capacity of (HAD) is 2100 (MW) consists of 12 turbines each generates 175 (MW). While the installed capacity of Old Aswan Dam (OAD) is 621 (MW) consists of 13 turbines. The power is estimated according to hydro turbine characteristic curves and power equation [9] (ME.2.05) as follow:

where:

$$
P=\eta * \rho * q * g * h
$$

$\mathrm{g}$ : acceleration of gravity, $(9.81 \mathrm{~m} / \mathrm{s} 2)$

h: net head (m)
P: power, (W)

$\mathrm{Q}$ out: water flow, (m3/s)

$\eta$ : efficiency ( 0.85 to 0.95$)$

\section{Hydroelectric power before filling time from Qattara Depression:}

The depression will take 20 years to be filled to level-50 (MSL) and will generate 7100 (million KWH). If it works $8000(\mathrm{H})$ annually, then the annual total power will be 56800 (MW).

\section{Hydroelectric power after filling time from Qattara Depression:}

The Ministry of Electricity and Energy suggested establishing hydropower station to work 4 (H/day) at a level from-60 to +215 (MSL) to generate 2400 (MW) and generate $4800(\mathrm{MW})$ if work 8 (H/day).

The storage at current target level of $175(\mathrm{~m})$ is 121.3 $(\mathrm{BCM})$ and the storage at target level of $170(\mathrm{~m})$ is 97.6 (BCM). Decreasing water level to $170(\mathrm{~m})$ upstream (HAD) will decrease evaporation and increase hydropower generation without probability risk in drought period.

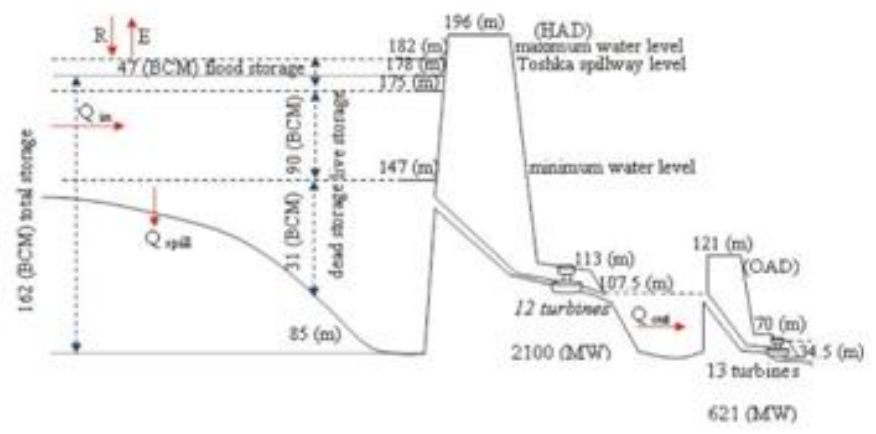

Figure14: Hydropower generation from Qattara Depression

\section{Conclusion}

To conclude the hole research main points, we did a comparison between each kind of energy applications (applied and hypothetical) in Egypt and their adversaries (peers) from different countries:

Wind power: after discussing [4], [5], and [6] Egypt in comparison to America has3 offshore available sites for 41 by $2022,4198 \mathrm{KM}^{\wedge} 2$ for $8622 \mathrm{~km}^{\wedge} 2$, Spent $5.505 \$$ Million for about 135 \$million in US, Total capacity of $33 \mathrm{GW}$ for 26.2 GW by 2022. Egypt has the potential to have sufficient generated electricity from wind energy only.

Solar energy: produces clean electricity and it's cheap. From solar energy, Egypt produces 1600 MW/Year but by applying the development (cooling techniques in Egypt) which was mentioned before the production might reach (1958.72: 2228.8) MW/Year. USA produces 1700 MW/Year but by applying the development of USA the production might reach (1768: 1870) MW/Year. [11, 12].

Hydroelectric energy: is relatively free of pollution and is renewable. But large hydroelectric plants disturb natural habitats, including the lifestyles of local communities. Qattara Depression has the super potentiality of generating 
clean hydro power during the filling period for a minimum of 20 years and has high potentiality after the filling period.

These three types of energy that the paper focused on are the most renewable energies used in the world. Every type is depending on the different energy sources to produce electricity, where all of them give higher results compared with any other type of energy. Most of the countries are depending on these three types (wind energy, solar power, and hydropower) as they don't cost much, and they also produce a low amount of greenhouse gas emissions.

\section{Suggested Recommendations}

According to the research it recommended some points to avoid the weakness points of the research of the three energy types as:

Wind energy: according to (fig 7) that shows the restrictions in Egypt which must be decreased to increase the area that can be used to applying the offshore system in Egypt. By increasing the offshore places, the electricity generated will be increased.

Solar energy: depending on the sunrise, so, to generate a good amount of these sunrises solar cells must be placed in sunny places. In Egypt the sunny places are the deserts. So, planting solar cells must be in deserts to benefit from these sunrises and to produce a good amount of electricity.

Hydropower energy: using small hydroelectric plants will reduce the problems of the large hydroelectric plants that disturb natural habitats. As small hydropower is very important to generate much electricity and supply water.

\section{Acknowledgement}

Great thankfulness and appreciation to anyone helped us to complete our mission especially;

- Ms. Noha Basiony Abd E-Samad (English supervisor and mentor)

- Mr. Mohamed Essam (Math mentor and supervisor)

\section{References}

[1] Kaygusuz, K. (2002). Sustainable Development of Hydroelectric Power. Energy Sources, 24 (9), 803815. doi: 10.1080/00908310290086725

[2] Salem, M. G. (2012). Water and Hydropower for Sustainable Development of Qattara Depression as a National Project in Egypt. Energy Procedia, 18, 9941004. doi: 10.1016/j. egypro.2012.05.114

[3] Yüksel, I. (2010). Hydropower for sustainable water and energy development. Renewable and Sustainable Energy Reviews, 14 (1), 462-469. doi: 10.1016/j. rser.2009.07.025

[4] Blaabjerg, F., \& Ma, K. (2013). Future on Power Electronics for Wind Turbine Systems. IEEE Journal of Emerging and Selected Topics in Power Electronics, 1 (3), 139-152. doi: 10.1109/jestpe.2013.2275978
[5] Mahdy, M., \& Bahaj, A. S. (2018). Multi criteria decision analysis for offshore wind energy potential in Egypt. Renewable Energy, 118, 278-289. doi: 10.1016/j. renene.2017.11.021

[6] Author, N. G. (2019).2018 Offshore Wind Technologies Market Report. doi: 10.2172/1559876

[7] Zumdahl, S. S., \& Zumdahl, S. A. (2014). Chemistry. Belmont, CA: Brooks/Cole, Cengage Learning.

[8] Walker, J., Resnick, R., \& Halliday, D. (2014). Halliday \& Resnick fundamentals of physics. Hoboken, NJ: Wiley.

[9] Sadler, A. J., \& Thorning, D. W. S. (1998). Understanding mechanics. Oxford: Oxford University Press.

[10] Gregg, B. A. (2005). The Photoconversion Mechanism of Excitonic Solar Cells. MRS Bulletin, 30 (1), 20-22. doi: $10.1557 / \mathrm{mrs} 2005.3$

[11] Solar Energy. (n. d.). Retrieved from https: //www.journals. elsevier. com/solar-energy

[12] Odeh, S., \& Behnia, M. (2009). Improving Photovoltaic Module Efficiency Using Water Cooling. Heat Transfer Engineering, 30 (6), 499-505. doi: 10.1080/01457630802529214

[13] (PDF) Solar energy: Potential and future prospects. Retrievedhttps: //www.researchgate net/publication/320264172_Solar_energy_Potential_a nd_future_prospects 